\title{
Sodium Aluminosilicate Fouling and Cleaning of Decontaminated Salt Solution Coalescers
}

M. R. Poirier

T. B. Peters

F. F. Fondeur

S. D. Fink

October 28, 2008 


\section{DISCLAIMER}

This report was prepared for the United States Department of Energy under Contract No. DE-AC09-08SR22470 and is an account of work performed under that contract. Neither the United States Department of Energy, nor SRNS, nor any of their employees makes any warranty, expressed or implied, or assumes any legal liability or responsibility for accuracy, completeness, or usefulness, of any information, apparatus, or product or process disclosed herein or represents that its use will not infringe privately owned rights. Reference herein to any specific commercial product, process, or service by trade name, trademark, name, manufacturer or otherwise does not necessarily constitute or imply endorsement, recommendation, or favoring of same by Savannah River Nuclear Solutions or by the United States Government or any agency thereof. The views and opinions of the authors expressed herein do not necessarily state or reflect those of the United States Government or any agency thereof.

Printed in the United States of America

Prepared For

U.S. Department of Energy 


\section{Reviews and Approvals}

\section{Authors}

M. R. Poirier, SRNL, Separations Science Programs

Date

T. B. Peters, SRNL, Separations Science Programs

Date

F. F. Fondeur, SRNL, Separations Science Programs

Date

Design Check

J. E. Laurinat, SRNL, Actinide Chemical Technology

Date

Management

S. D. Fink, Manager, SRNL, Separations Science Programs

Date

J. C. Griffin, Manager, SRNL E\&CPT Research Programs

Date

\section{Customer}

G. C. Arthur, H Tank Farm Engineering

Date 


\section{SUMMARY}

During initial non-radioactive operations at the Modular Caustic Side Solvent Extraction Unit (MCU), the pressure drop across the decontaminated salt solution coalescer reached 10 psi while processing 1250 gallons of salt solution, indicating possible fouling or plugging of the coalescer. An analysis of the feed solution and the "plugged coalescer" concluded that the plugging was due to sodium aluminosilicate solids. MCU personnel requested Savannah River National Laboratory (SRNL) to investigate the formation of the sodium aluminosilicate solids (NAS) and the impact of the solids on the decontaminated salt solution coalescer. Researchers performed developmental testing of the cleaning protocols with a bench -scale coalescer container 1-inch long segments of a new coalescer element fouled using simulant solution. In addition, the authors obtained a "plugged” Decontaminated Salt Solution coalescer from nonradioactive testing in the MCU and cleaned it according to the proposed cleaning procedure.

Conclusions from this testing include the following.

- Testing with the bench-scale coalescer showed an increase in pressure drop from solid particles, but the increase was not as large as observed at MCU.

- Cleaning the bench-scale coalescer with nitric acid reduced the pressure drop and removed a large amount of solid particles (11 $\mathrm{g}$ of bayerite if all aluminum is present in that form or $23 \mathrm{~g}$ of sodium aluminosilicate if all silicon is present in that form).

- Based on analysis of the cleaning solutions from bench-scale test, the "dirt capacity" of a 40 inch coalescer for the NAS solids tested is calculated as 450 - 950 grams.

- Cleaning the full-scale coalescer with nitric acid reduced the pressure drop and removed a large amount of solid particles (60 $\mathrm{g}$ of aluminum and $5 \mathrm{~g}$ of silicon).

- Piping holdup in the full-scale coalescer system caused the $\mathrm{pH}$ to differ from the target value. Comparable hold-up in the facility could lead to less effective cleaning and precipitation of bayerite solid particles.

- Based on analysis of the cleaning solutions from the full-scale test, the "dirt capacity" of a 40 inch coalescer for these NAS solids was calculated to be $40-170$ grams.

\section{INTRODUCTION}

During initial operations at the MCU, the pressure drop across the Decontaminated Salt Solution coalescer reached $\sim 10$ psi while processing $\sim 1250$ gallons of salt solution, indicating possible fouling or plugging of the coalescer. An analysis of the feed solution and the "plugged coalescer" concluded that the plugging was due to sodium aluminosilicate solids. $1,2,3$

MCU personnel requested SRNL to investigate the formation of the sodium aluminosilicate solids and the impact of the solids on the decontaminated salt solution coalescer. The impact of solid particles on a coalescer or filter element is quantified as the "dirt capacity" of the coalescer element - i.e., the amount of solids that can deposit on the element before flow becomes prohibitively low. The vendor was not able to provide a "dirt capacity" for the MCU application. The authors conducted a bench-scale coalescer test to measure the amount of sodium aluminosilicate needed to plug the coalescer and to assess the adequacy of the produced nitric acid cleaning regime prior to testing with the only available fouled element from MCU. 
Following the bench-scale testing, the authors cleaned a fouled coalescer from the MCU according to proposed cleaning procedure for MCU. Prior to radioactive startup, MCU personnel removed the coalescer from service and delivered it to SRNL in January 2008. The purpose of this test was to assess the proposed cleaning procedure and recommend improvements, if any, in the cleaning protocols.

\section{TESTING}

\section{Bench-Scale Coalescer Fouling Test}

Figure 1 shows the bench-scale coalescer unit. The housing is manufactured by Pall Trinity Corp. (part \# 5HD4886-799) and is designed to hold a 1 inch cartridge filter. Personnel modified the unit to hold a 1 inch coalescer element. They obtained a 40-inch, unused coalescer element from MCU personnel. They cut a 1 inch section from the coalescer, soaked it in Isopar ${ }^{\circledR} \mathrm{L}$, and placed it in the housing.

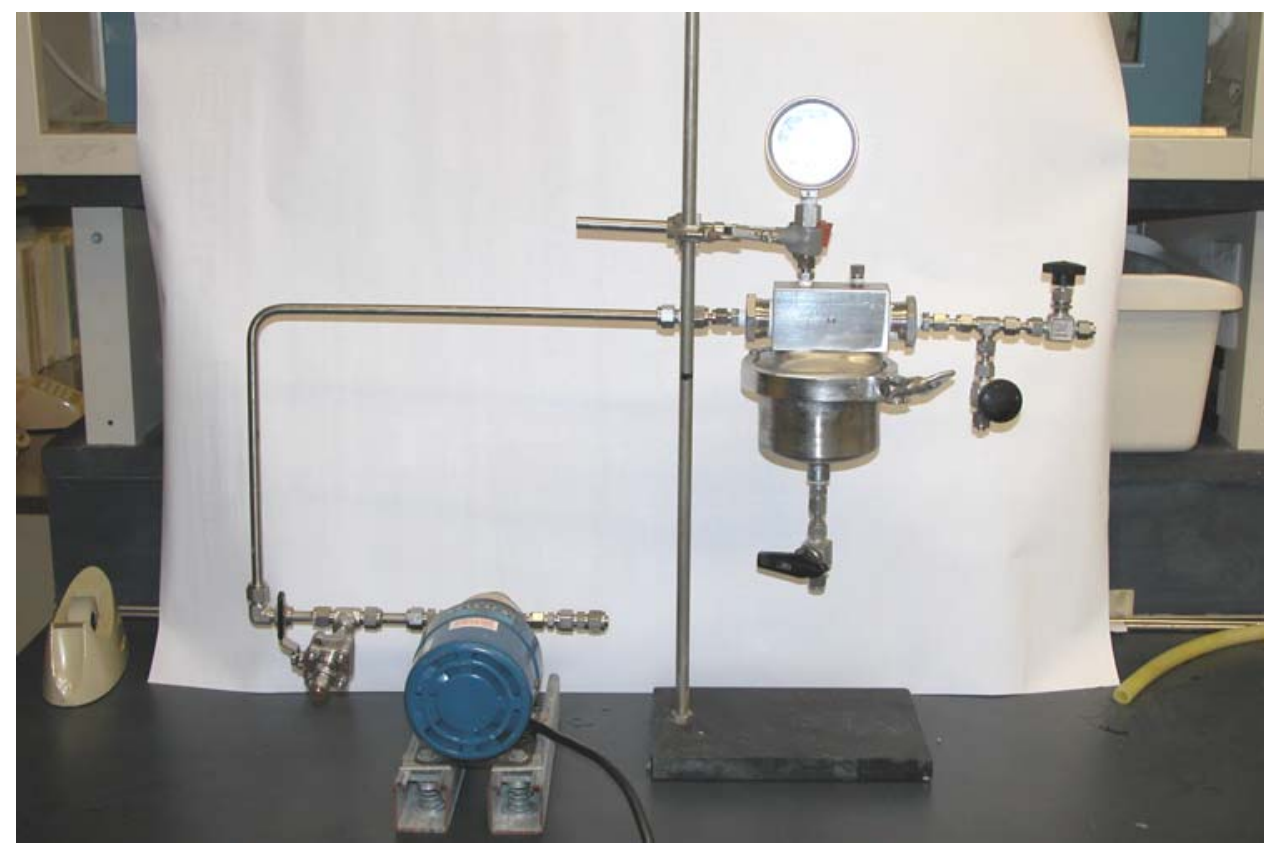

Figure 1. Bench-Scale Coalescer Unit

Personnel prepared $50 \mathrm{~L}$ of simulated MCU feed with the composition shown in Table 1 . They heated the solution to $40{ }^{\circ} \mathrm{C}$ and held it at temperature for 24 hours. The heating cycle simulated the treatment applied by the vendor for the initial simulant solutions used in MCU that resulted in fouling of coalescers. After 24 hours, they allowed the solution to cool to $25^{\circ} \mathrm{C}$ and collected feed samples. They analyzed samples for turbidity. 
Table 1. Simulated MCU Feed Solution

\begin{tabular}{|l|c|}
\hline Component & Concentration (M) \\
\hline $\mathrm{NaOH}$ & 2.06 \\
\hline $\mathrm{NaNO}_{3}$ & 2.03 \\
\hline $\mathrm{NaNO}_{2}$ & 0.500 \\
\hline $\mathrm{Al}_{2}\left(\mathrm{NO}_{3}\right)_{3} * 9 \mathrm{H}_{2} \mathrm{O}$ & 0.280 \\
\hline $\mathrm{Na}_{2} \mathrm{SO}_{4}$ & 0.140 \\
\hline $\mathrm{Na} 2 \mathrm{CO}_{3} * \mathrm{H}_{2} \mathrm{O}$ & 0.150 \\
\hline $\mathrm{NaCl}$ & 0.0240 \\
\hline $\mathrm{NaF}$ & 0.0280 \\
\hline $\mathrm{Na}_{2} \mathrm{HPO}_{4} * 7 \mathrm{H}_{2} \mathrm{O}$ & 0.0070 \\
\hline $\mathrm{Na}_{2} \mathrm{C}_{2} \mathrm{O}_{4}$ & 0.020 \\
\hline $\mathrm{Na}_{2} \mathrm{SiO}_{3} * 9 \mathrm{H}_{2} \mathrm{O}$ & 0.030 \\
\hline $\mathrm{Na}_{2} \mathrm{MoO}_{4} * 2 \mathrm{H}_{2} \mathrm{O}$ & 0.00007 \\
\hline
\end{tabular}

After the feed solution cooled to $25^{\circ} \mathrm{C}$, personnel connected the feed line from the coalescer to the carboy holding the feed solution. They connected the product line to an empty $52 \mathrm{~L}$ carboy. They pumped the feed solution through the coalescer at $\sim 0.225$ gpm and recorded the feed pressure and feed flow rate periodically. This flow rate is based on the coalescer area being $1 / 40^{\text {th }}$ of full-scale and using the maximum flow rate through the full-scale coalescer of 9 gpm.

After the feed solution transferred to the product tank, they stopped the feed pump and returned the solution to the feed carboy. They connected the product line to the feed tank. They recirculated the feed solution through the coalescer and measured the feed pressure and feed rate periodically. After 4 hours, they stopped the feed pump. They added an additional $318 \mathrm{~g}$ of $\mathrm{Na}_{2} \mathrm{SiO}_{3} * 9 \mathrm{H}_{2} \mathrm{O}$ to produce a silicon concentration of $0.06 \mathrm{M}$, heated the solution to $40^{\circ} \mathrm{C}$ for 24 hours, and allowed the solution to sit for three days. (The $0.06 \mathrm{M}$ silica concentration approximated the revised vendor specification value used in the final period of non-radioactive testing in the facility.) After three days, they recirculated the feed solution through the coalescer at $\sim 0.225$ gpm for 6.5 hours, periodically monitoring pressure and flow rate.

They cleaned the coalescer as follows. They prepared $8 \mathrm{~L}$ of $1 \mathrm{M}$ nitric acid. They recirculated the acid through the coalescer for one hour. After one hour, they allowed the coalescer to soak for an additional two hours. Following the soak, they drained the coalescer housing.

They recirculated salt solution (see Table 1) through the coalescer for 1 hour monitoring pressure and feed flow rate.

\section{Full-Scale Coalescer Cleaning Test}

The authors obtained a full-scale coalescer element used and "plugged” during MCU simulant testing. (During facility operations, the high alarm pressure for the coalescer was 18 psig. When pressure exceeded this value, Operations stopped use and removed the element. They shipped this element to SRNL.) SRNL installed the element in the apparatus previously used for coalescer testing at Wright Industries, Inc., and in more recent SRNL testing (see Figure 2). ${ }^{4}$ 


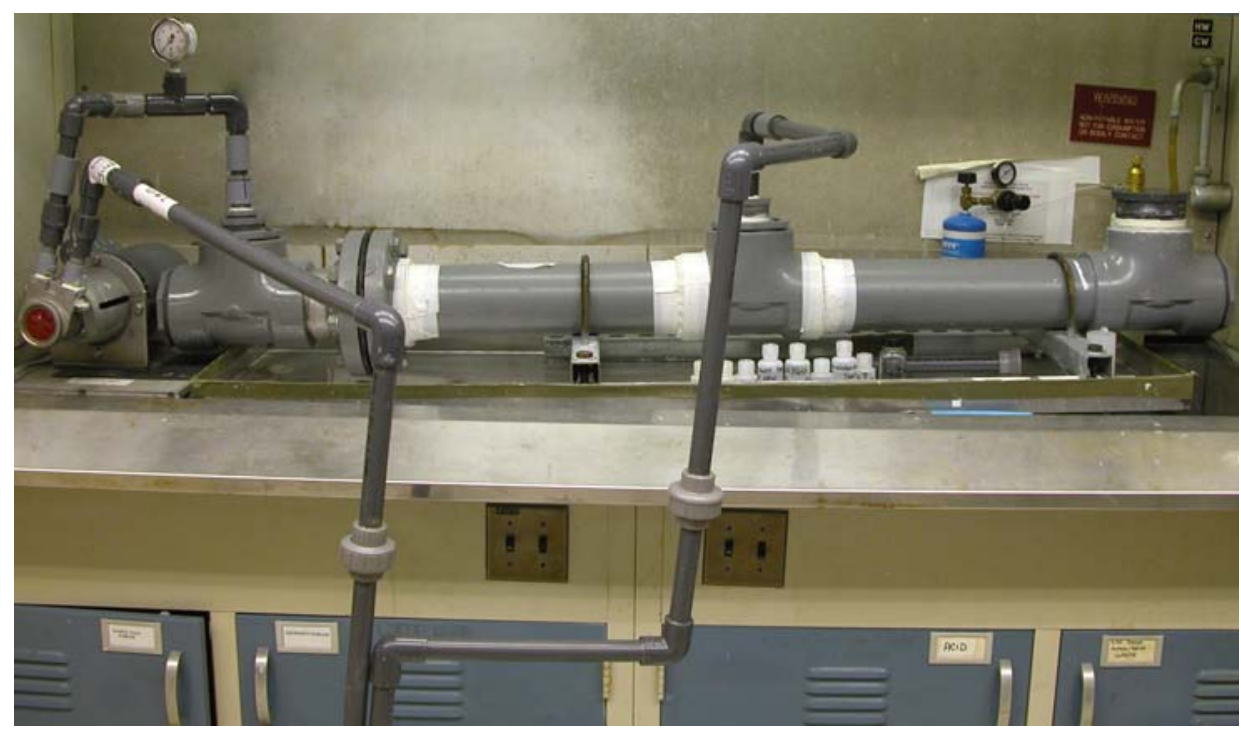

Figure 2. Full-Scale Coalescer Test Unit

They prepared 50 L of salt solution containing 2.20 M sodium hydroxide, 2.46 M sodium nitrate, $0.60 \mathrm{M}$ sodium nitrite, and $0.36 \mathrm{M}$ sodium aluminate. They recirculated the solution through the coalescer for one hour. They measured the pressure across the coalescer. This data indicates the degree of fouling of the coalescer.

They cleaned the coalescer according to the MCU proposed coalescer cleaning procedure. ${ }^{5}$ They drained the coalescer housing. They flushed the coalescer with $0.85 \mathrm{M}$ nitric acid, until they observed liquid exiting the coalescer housing. They allowed the coalescer to soak in nitric acid for eight hours. Following the eight hour soak, they recirculated fresh, $0.85 \mathrm{M}$ nitric acid through the coalescer for 25 minutes. (The 25 min recirculation period approximates the flushing time anticipated in the facility operation for those steps.) They drained the nitric acid and recirculated deionized water through the coalescer for 25 minutes. They drained the deionized water and recirculated $0.01 \mathrm{M}$ sodium hydroxide through the coalescer for 25 minutes. They drained the dilute sodium hydroxide solution from the coalescer and soaked the coalescer with $6 \mathrm{~L}$ of $0.1 \mathrm{M}$ sodium hydroxide. Following this soak, they recirculated simulated salt solution through the coalescer and measured the flux. Following the recirculation, they soaked the coalescer in $3 \mathrm{M}$ nitric acid for six hours to attempt to dissolve any solid particles remaining.

During the cleaning process, they collected samples after each step and analyzed them for $\mathrm{pH}$ and metals by inductively-coupled plasma emission spectroscopy (ICP-ES).

\section{RESULTS}

\section{Bench-Scale Coalescer Fouling Test}

Figure 3 shows the equivalent pressure drop of the coalescer as a function of time. In this figure, we normalized the measured pressure drop to the equivalent pressure drop for a 40 inch coalescer element at $8.5 \mathrm{gpm}$. We multiplied the measured pressure drop by the ratio of flow rates (8.5 gpm/test flow rate) and divided by 40 (to account for the difference in coalescer 
length). Figure 4 shows the same data plotted in terms of filter permeance, or flux divided by pressure drop. Permeance is the coalescer flux divided by the pressure drop. This parameter allows one to compare measurements taken at different flow rates and pressure drops. The pressure drop of the salt solution was approximately twice that of the water. Given that the viscosity of the salt solution is $\sim 2 \mathrm{cp}$ and the viscosity of deionized was is $\sim 1 \mathrm{cp}$, one expects a $2 \mathrm{X}$ increase. After cleaning with nitric acid, the pressure drop decreased $\sim 2.5 \mathrm{X}$. The pressure drop for fresh salt solution after cleaning was half that of salt solution with sodium aluminosilicate.

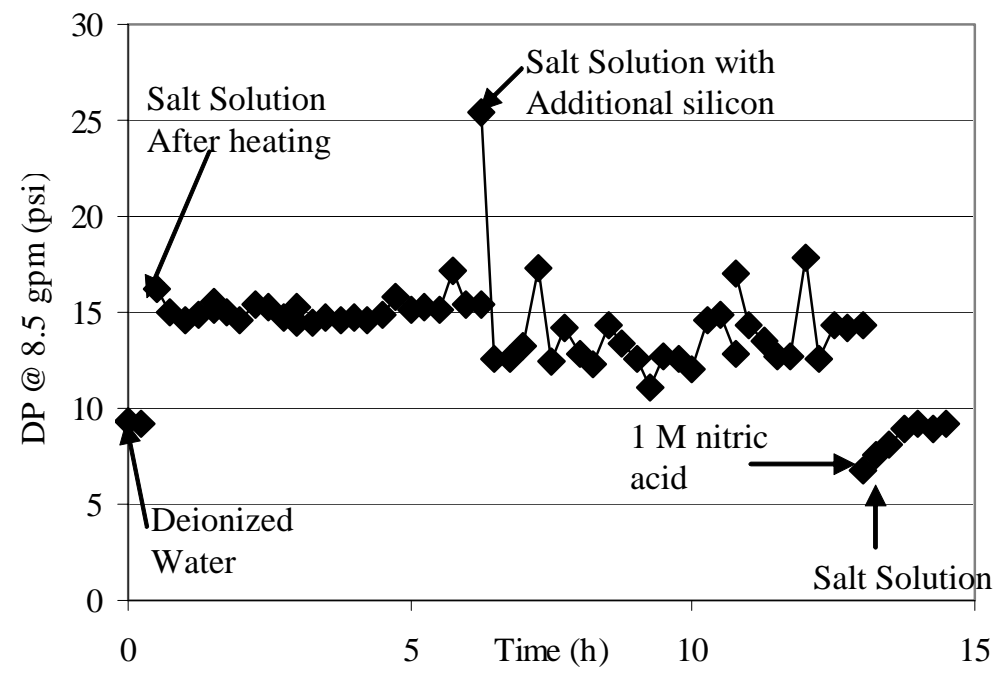

Figure 3. Coalescer Pressure Drop

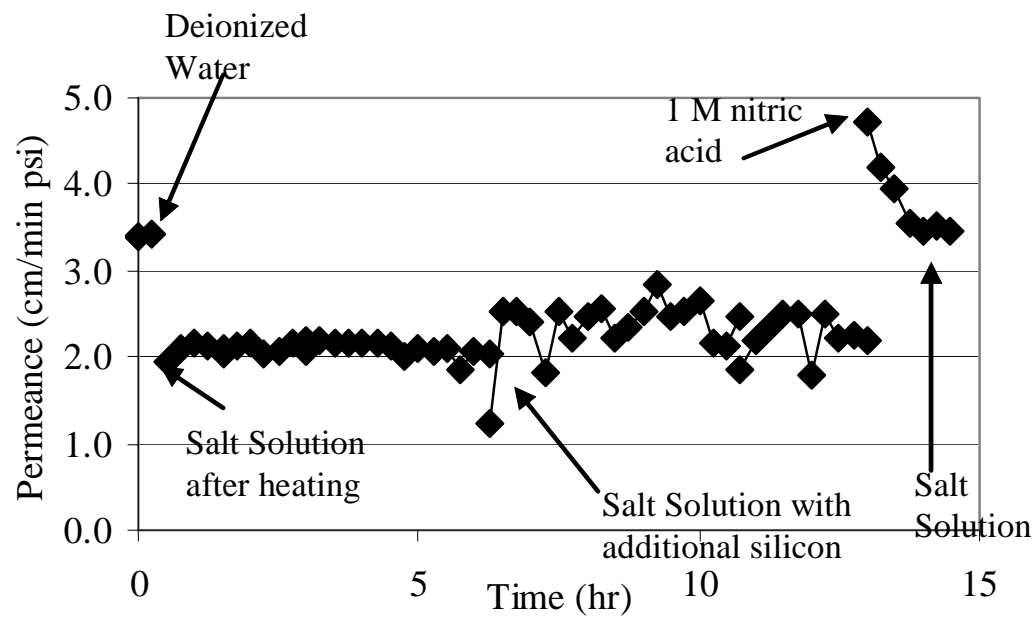

Figure 4. Coalescer Permeance

Table 2 shows the metals measured in the cleaning solution. Based on the measured elemental concentrations and the volume of solution, we calculate the mass of solids based on bayerite $\left(\mathrm{Al}(\mathrm{OH})_{3}\right)$ and based on sodium aluminosilicate $\left(\mathrm{Na}_{2} \mathrm{OAl}_{2} \mathrm{O}_{3} 1.68 \mathrm{SiO}_{2} * 1.8 \mathrm{H}_{2} \mathrm{O}\right)$. If the coalescer was fouled with bayerite, the mass of bayerite equated to $11.4 \mathrm{~g}$ (or $456 \mathrm{~g}$ for a 40 inch element). 
If the coalescer was fouled with sodium aluminosilicate, the mass of sodium aluminosilicate equated to $23.5 \mathrm{~g}$ (or $940 \mathrm{~g}$ for a 40 inch element).

Table 2. Metals Measured in Cleaning Solution

\begin{tabular}{|l|c|c|}
\hline Species & Acid Rinse Solution $(\mathrm{mg} / \mathrm{L})$ & Final Drain $(\mathrm{mg} / \mathrm{L})$ \\
\hline $\mathrm{Al}$ & 384 & 1730 \\
\hline $\mathrm{Ca}$ & 1.30 & 8.75 \\
\hline $\mathrm{Fe}$ & 0.943 & 3.24 \\
\hline $\mathrm{Na}$ & 2880 & 9810 \\
\hline $\mathrm{P}$ & 4.02 & 15.1 \\
\hline $\mathrm{S}$ & 96.2 & 338 \\
\hline $\mathrm{Si}$ & 261 & 1190 \\
\hline $\mathrm{Zn}$ & 0.271 & 13.9 \\
\hline Volume & $8 \mathrm{~L}$ & $0.50 \mathrm{~L}$ \\
\hline Equivalent Bayerite & $8.9 \mathrm{~g}$ & $2.5 \mathrm{~g}$ \\
\hline Equivalent Sodium Aluminosilicate & $18.3 \mathrm{~g}$ & $5.2 \mathrm{~g}$ \\
\hline
\end{tabular}

\section{Full-Scale Coalescer Cleaning Test}

The simulated salt solution had a density of $1.2 \mathrm{~g} / \mathrm{mL}$ (@ $20.8{ }^{\circ} \mathrm{C}$ ), a pH of 14, and a turbidity of $0.21-0.36$ NTU. Personnel recirculated the salt solution through the coalescer for approximately one hour. The steady-state feed pressure measured 20 psi (see Figure 5), in reasonable agreement with the performance reported by the facility in earlier operations for this element. They stopped the pumping and drained the coalescer housing and piping. 


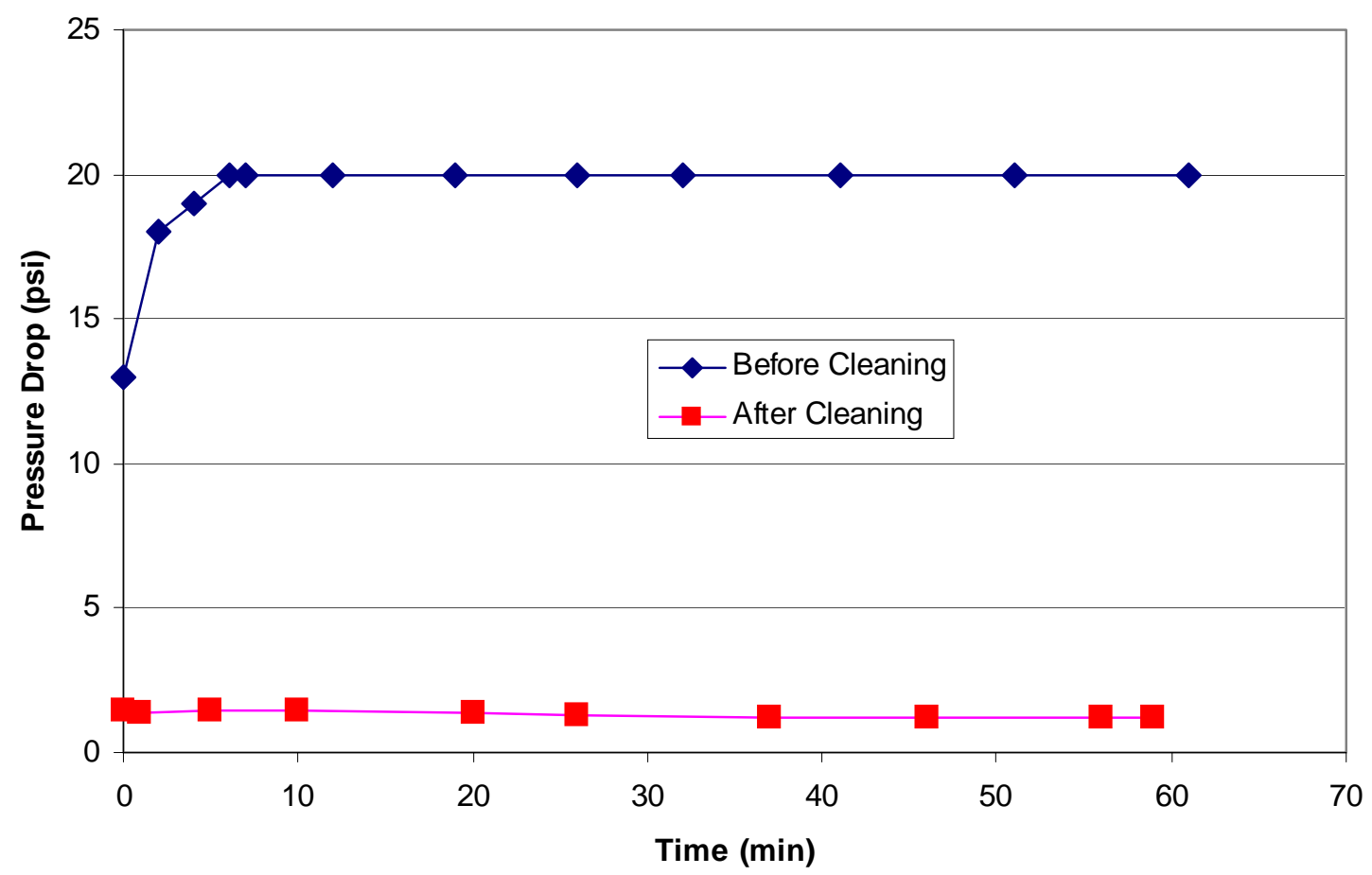

Figure 5. Pressure Drop across Coalescer before and After Cleaning.

They filled the feed tank with $40 \mathrm{~L}$ of $0.85 \mathrm{M}$ nitric acid and pumped the acid through the coalescer until approximately 10 gallons collected in the product tank. During the pumping, the feed pressure never exceeded 12 psi and dropped rapidly (i.e., within 1-2 minutes of starting to add the acid) to $<5$ psi. They allowed the coalescer to soak for eight hours. The $\mathrm{pH}$ of the soak acid was $>11$ as measured subsequently to the soak period. The high $\mathrm{pH}$ indicates that a large amount of sodium hydroxide remained in the coalescer housing following draining. Based upon $\mathrm{pH}$ and sodium measurements, we estimate the hold up as $7-18 \%$ of the volume. The rapid drop in pressure upon initial addition of acid indicates that the cleaning solution removed some of the contaminants that fouling the coalescer.

After eight hours, they drained the acid from the soak and recirculated $0.85 \mathrm{M}$ nitric acid through the coalescer for 25 minutes. The low pressure (i.e., less than resolution of pressure gauge) (see Figure 5) indicates that the cleaning solution removed a significant fraction of the contaminants that were fouling the coalescer.

After 25 minutes, they removed the nitric acid from the coalescer unit and filled the feed tank with $25 \mathrm{~L}$ of deionized water. They recirculated the water through the coalescer for 25 minutes. The $\mathrm{pH}$ was $\sim 1$. The feed pressure was $<3$ psi. The low $\mathrm{pH}$ indicates that a large amount of acid remained in the coalescer housing following draining.

After 25 minutes, they removed the water from the coalescer unit and filled the feed tank with $25 \mathrm{~L}$ of $0.01 \mathrm{M} \mathrm{NaOH}$. They recirculated the $\mathrm{NaOH}$ through the coalescer for 25 minutes. The 
$\mathrm{pH}$ was $\sim 1$. The feed pressure remained $<3$ psi. The low $\mathrm{pH}$ indicates that a large amount of acid remained in the coalescer housing following draining.

Because of the low $\mathrm{pH}$ following the dilute $\mathrm{NaOH}$ flush, an additional $\mathrm{NaOH}$ soak was performed. Personnel prepared $6 \mathrm{~L}$ of $0.1 \mathrm{M} \mathrm{NaOH}$. They drained the coalescer unit and added the $\mathrm{NaOH}$ directly to the coalescer housing. They allowed it to soak for 15 minutes. After 15 minutes, the $\mathrm{pH}$ of the solution was $>11$.

They drained the housing and added simulated salt solution to the feed tank. They recirculated the simulated salt solution through the coalescer for one hour. The feed pressure varied between $1.2-1.5$ psi. The $\mathrm{pH}$ was $>11$.

Table 3 shows the metals measured by ICPES and the $\mathrm{pH}$. It also shows the estimated volume of the coalescer apparatus heel based on the $\mathrm{pH}$ and sodium measurements. The heel is estimated to be $7-18 \%$ of the system volume.

Table 3. Metals Measured in Cleaning Solutions

\begin{tabular}{|c|c|c|c|c|c|c|}
\hline Sample & $\underline{\mathrm{Al}(\mathrm{M})}$ & $\underline{\mathrm{Na}(\mathrm{M})}$ & $\underline{\mathrm{Si}(\mathrm{M})}$ & $\mathrm{pH}$ & $\frac{\text { Heel }}{(\mathrm{Na})}^{*}$ & $\frac{\mathrm{Heel}^{*}}{(\mathrm{pH})}$ \\
\hline $\begin{array}{l}\text { Nitric acid } \\
\text { cleaning solution } \\
\text { before soak }\end{array}$ & 0.0567 & 0.891 & 0.00295 & 1 & & \\
\hline $\begin{array}{l}\text { Nitric acid } \\
\text { cleaning solution } \\
\text { after soak }\end{array}$ & 0.0459 & 0.700 & 0.00457 & 1 & $12.5 \%$ & $16 \%$ \\
\hline $\begin{array}{l}\text { Post deionized } \\
\text { water flush }\end{array}$ & 0.0052 & 0.083 & 0.00026 & 1 & $11.8 \%$ & \\
\hline $\begin{array}{l}\text { Post } 0.01 \mathrm{M} \\
\mathrm{NaOH} \text { flush }\end{array}$ & 0.0024 & 0.047 & 0.00005 & 2 & & $18 \%$ \\
\hline $\begin{array}{l}\text { Post } 0.1 \mathrm{M} \\
\mathrm{NaOH} \text { soak }\end{array}$ & 0.0002 & 0.100 & $<0.000009$ & 13 & & \\
\hline $\begin{array}{l}\text { Post salt solution } \\
\text { recirculation }\end{array}$ & 0.2996 & 5.217 & $<0.00009$ & 14 & $7.0 \%$ & \\
\hline $\begin{array}{l}\text { Post 3M nitric } \\
\text { acid soak }\end{array}$ & 0.0504 & 0.861 & $<0.000009$ & 0.5 & $16.5 \%$ & \\
\hline Salt solution & 0.3222 & 5.609 & & 1 & & \\
\hline
\end{tabular}

Table 4 shows the amount of aluminum, sodium, and silicon recovered from the cleaning solutions. In addition, the table calculates the equivalent amount of solids collected assuming that all of the aluminum was present as bayerite $\left[\mathrm{Al}(\mathrm{OH})_{3}\right]$ or all of the silicon was present as sodium aluminosilicate $\left[\mathrm{Na}_{2} \mathrm{OAl}_{2} \mathrm{O}_{3} \cdot 1.68 \mathrm{SiO}_{2} \cdot 1.8 \mathrm{H}_{2} \mathrm{O}\right]$ 
Table 4. Metals Recovered from Cleaning Solutions

\begin{tabular}{|l|c|c|c|c|}
\hline Sample & $\underline{\text { Volume }(\mathrm{L})}$ & $\underline{\mathrm{Al}(\mathrm{g})}$ & $\underline{\mathrm{Na}(\mathrm{g})}$ & $\underline{\mathrm{Si}(\mathrm{g})}$ \\
\hline $\begin{array}{l}\text { Nitric acid } \\
\text { cleaning solution } \\
\text { before soak }\end{array}$ & 10 & 15.3 & 204.9 & 0.95 \\
\hline $\begin{array}{l}\text { Nitric acid } \\
\text { cleaning solution } \\
\text { after soak }\end{array}$ & 25 & 31.0 & 402.5 & 3.68 \\
\hline $\begin{array}{l}\text { Post deionized } \\
\text { water flush }\end{array}$ & 25 & 3.51 & 47.7 & 0.21 \\
\hline $\begin{array}{l}\text { Post 0.01 M } \\
\text { NaOH flush }\end{array}$ & 25 & 1.62 & 27.0 & $<0.04$ \\
\hline $\begin{array}{l}\text { Post 0.1 M } \\
\text { NaOH soak }\end{array}$ & 6 & 0.032 & 13.8 & $<0.0017$ \\
\hline $\begin{array}{l}\text { Post 3M nitric } \\
\text { acid soak }\end{array}$ & 6 & 5.2 & 118.8 & $<0.0017$ \\
\hline Total Recovered & & 172 & & 4.84 \\
\hline $\begin{array}{l}\text { Equivalent } \\
\text { Solids as } \\
\text { Bayerite }\end{array}$ & & & & 42.5 \\
\hline $\begin{array}{l}\text { Equivalent } \\
\text { Solids as Sodium } \\
\text { Aluminosilicate }\end{array}$ & & & & \\
\hline
\end{tabular}

\section{Post Mortem Examination of Fouled and Cleaned Coalescer Media}

To ensure the absence of particles throughout the coalescer (and not the selective cleaning of a region), researchers cut small portions from different locations along the coalescer. The sections were examined under an optical microscope at $10 \mathrm{X}$ magnification to observe the pore space between the coalescer fibers. One of the authors used image software (JIMAGE) to calculate the free space in the coalescer. Figure 6 shows pictures of the interior surface (inside diameter) and exterior surface (outside diameter) at the inlet section of the coalescer. The inside surface of the coalescer was wet (containing both water and Modifier ${ }^{i}$ as verified by FTIR: See Figure 7). The water resided between the fibers. The Modifier was found sorbed on the fiber. At the inlet of coalescer, some areas ( $20 \%$ of the visible area at the entrance considered to be 5 inches from the inlet to the coalescer were still covered with a layer of solids (as shown in Figure 6b) and others had few solids (Figure 6a). The exterior surface was drier (as shown in Figure 6c). However, the calculated porosity of the interior and exterior surfaces were similar $63 \%$ (picture a) versus $68 \%$ (picture b).

\footnotetext{
${ }^{\mathrm{i}}$ An alkylphenoxy alcohol modifier (1-(2,2,3,3-tetrafluoropropoxy)-3-(4-sec-butylphenoxy)-2-propanol, also known as Cs-7SB) added to the solvent enhances the extraction power of the calixarene and prevents the formation of a third phase.
} 


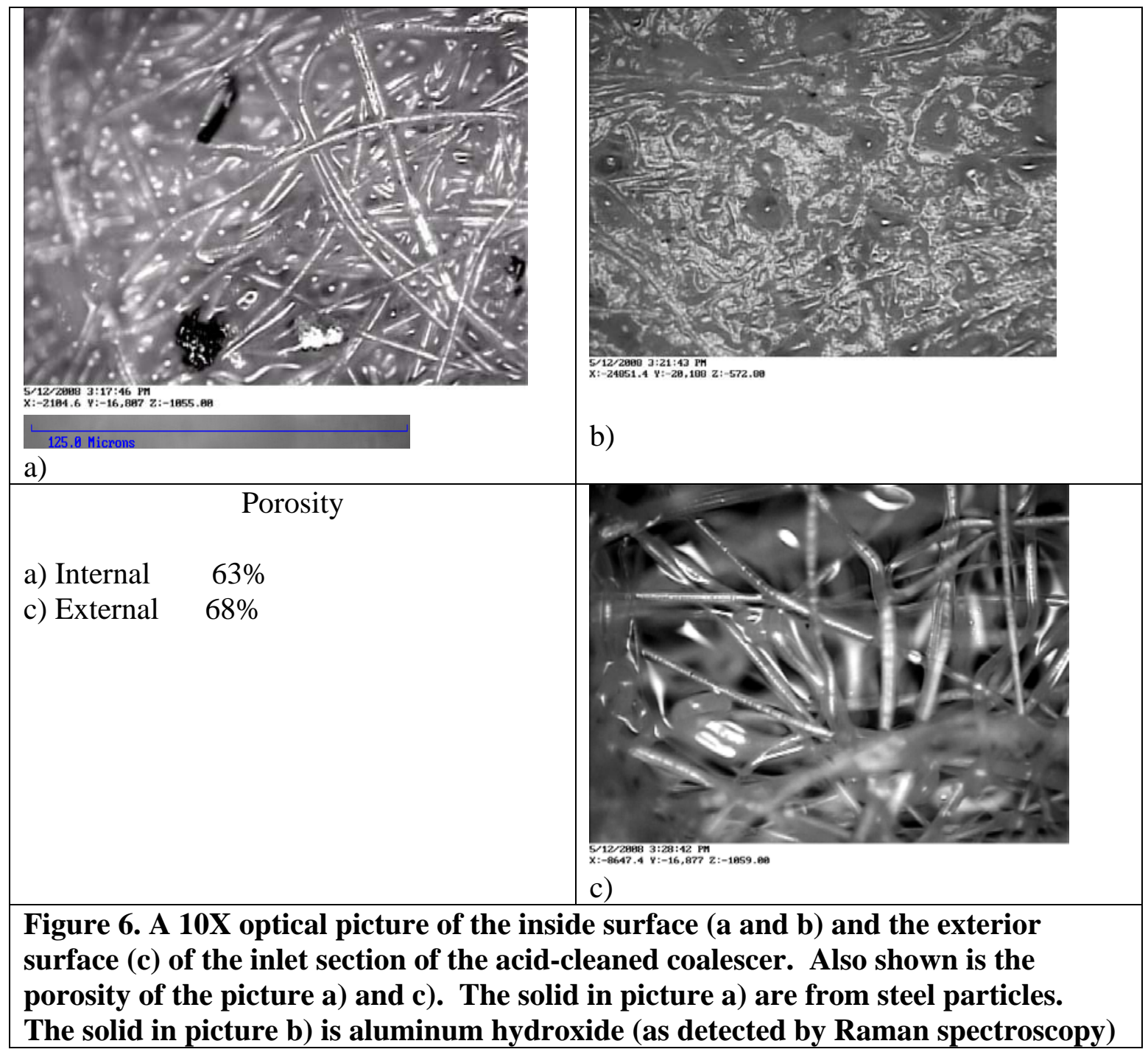

Similarly, an examination of a section from the dead-end of the coalescer revealed a similar pattern as observed from the inlet section. Figure 8 shows the optical pictures (at 10X magnification) of the interior and exterior surface of the coalescer. Some areas of the interior surfaces were covered with solids (as in Figure 8 b) while the remaining areas ( $80 \%$ ) had no discernable solids (Figure $8 a$ ). The exterior surface was mostly clean of particles (as shown in Figure 8c) although Modifier was found absorbed on the fibers (as detected by FTIR spectroscopy: See Figure 7). Figure 8d shows an image of the Modifier as spotty thin film of liquid on a fiber. Evidence of modifier was seen throughout the coalescer. The photo suggests that the modifier preferentially wets the coalescer relative to Isopar ${ }^{\circledR} \mathrm{L}$ and other organic constituents and that a trace amount of Modifier is removed from the decontaminated salt solution by this mechanism. 


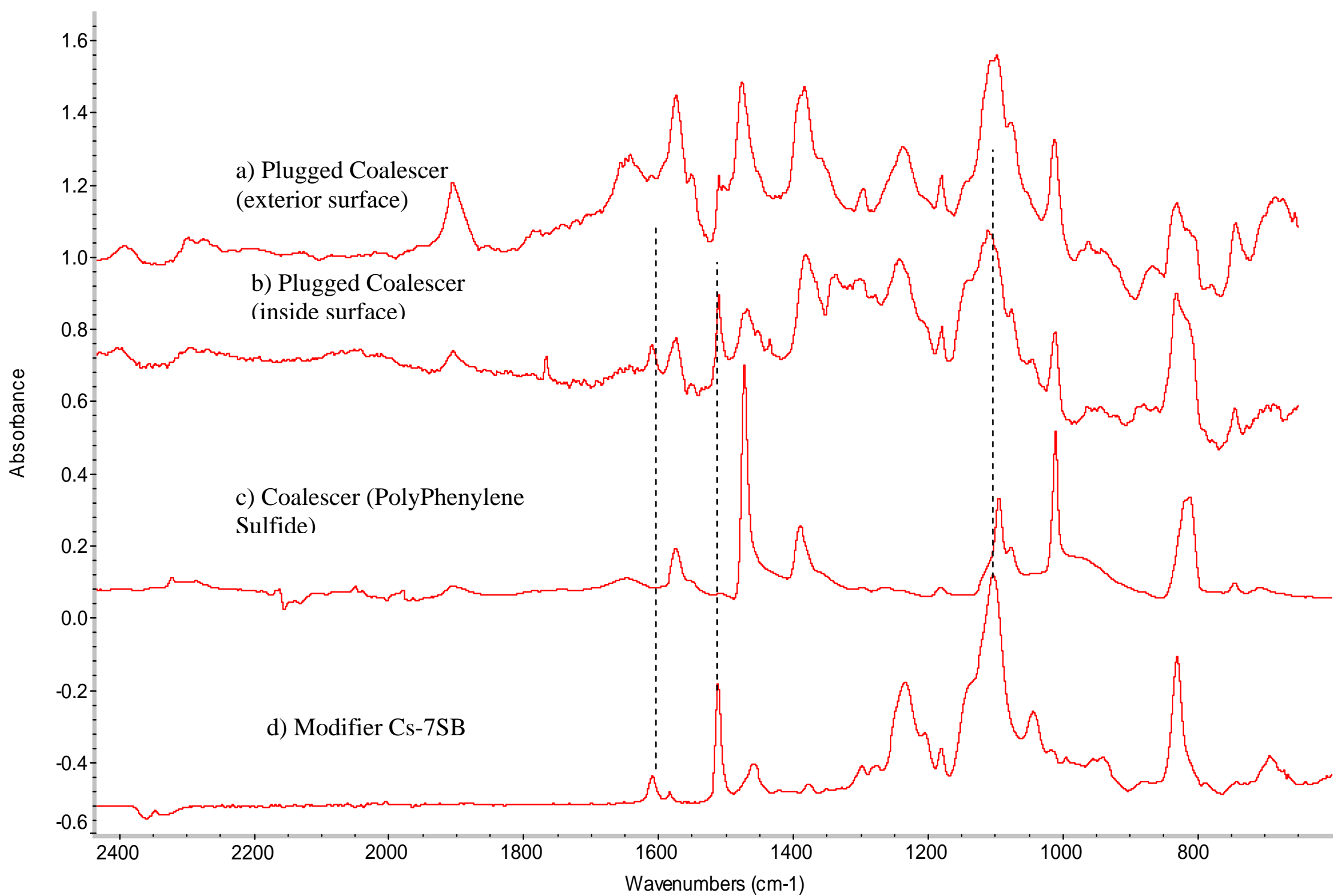

Figure 7. The FTIR microscopic spectra of the exterior and interior surfaces of the plugged coalescer. 


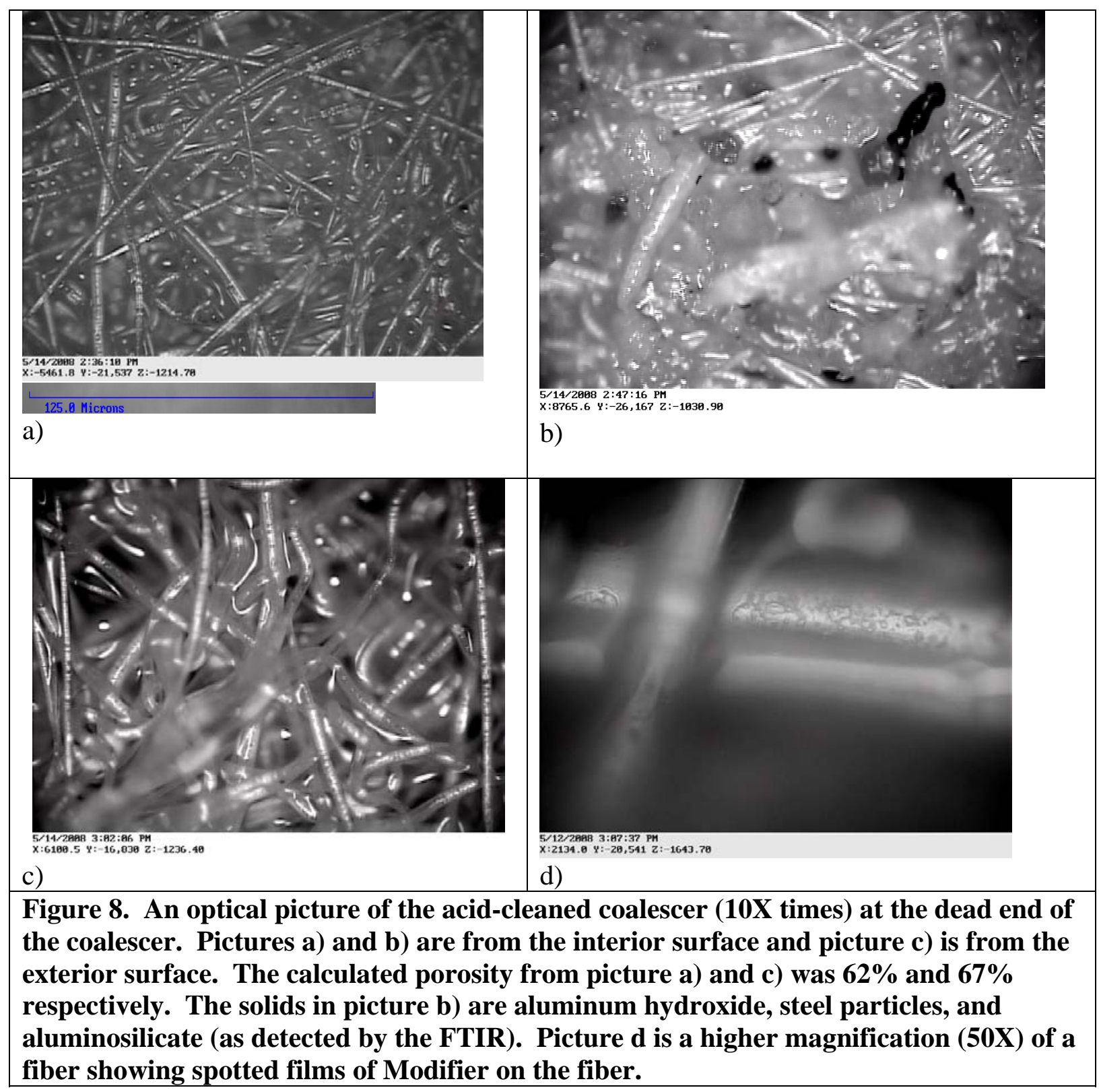

Using the image software, the authors estimated the amount of Modifier collected on the coalescer fibers. They considered two cases. In case one, they estimated the volume occupied by droplets in a small section of the coalescer. In this case, the volume of Modifier per area of coalescer was $5.1 \times 10^{-13} \mathrm{~mL} / 2.383 \times 10^{-8} \mathrm{~cm}^{2}$. In the second case, they estimated the Modifier film thickness over a small fraction of the coalescer. In this case, the volume of Modifier per area of coalescer was $3.83 \times 10^{-13} \mathrm{~mL} / 2.383 \times 10^{-8} \mathrm{~cm}^{2}$. From these volumes, the coalescer surface area $\left(811 \mathrm{~cm}^{2}\right)$, and the Modifier density $(1.197 \mathrm{~g} / \mathrm{mL})$, we calculated the amount of Modifier collected at the coalescer by equations [1] and [2].

$$
\begin{aligned}
& \left(811 \mathrm{~cm}^{2}\right)\left(5.1 \times 10^{-13} \mathrm{~mL} / 2.383 \times 10^{-8} \mathrm{~cm}^{2}\right)(1.197 \mathrm{~g} / \mathrm{mL})=0.02 \mathrm{~g} \\
& \left(811 \mathrm{~cm}^{2}\right)\left(3.83 \times 10^{-13} \mathrm{~mL} / 2.383 \times 10^{-8} \mathrm{~cm}^{2}\right)(1.197 \mathrm{~g} / \mathrm{mL})=0.016 \mathrm{~g}
\end{aligned}
$$


The Modifier will sorb throughout the coalescer rather than just at the surface. The coalescer media is $1.9 \mathrm{~cm}$ thick and the fibers are approximately 20 micron in diameter. Dividing the coalescer into 50 micron sections yields 380 sections. Multiplying the amount of Modifier collected on the surface by 380 yields 6 grams of Modifier sorbed on the coalescer fibers. Assuming 100 gallons of solvent, the mass of Modifier is calculated with equation [3]

$$
(100 \text { gal)(3785 mL/gal)(0.298)(0.855 g/mL) = 96,438 g Modifier }
$$

This calculation shows that the amount of Modifier collected on the coalescer fibers is a very small fraction of the total Modifier passing through the coalescer and will not affect the composition of the solvent.

Researchers calculated the percent of porosity blocked by the precipitated particles in the inlet circular area of a coalescer that experience a pressure increase during service. Figure 9 shows a picture a $2.5 \mathrm{~mm}$ circular of the coalescer (area exposed by the porous stainless steel inner tube). Imaging software was then used to calculate the percent viewing area occupied by the precipitates. In this picture, the precipitates occupy $13-15 \%$ of the viewing area. This reduces the porosity to $50 \%$ compare to the $65 \%$ area available in the "as received" coalescer. The calculation does not include any fiber diameter increase due to adsorption which requires a higher magnification.

In conclusion, the calculated porosity was the same throughout the coalescer (average $65 \%$ ). No evidence of selective cleaning along the length of the coalescer was seen. Groupings of particles of steel, aluminum hydroxide and aluminosilicate were found along the interior surface of the coalescer (steel particle were seen on the exterior surface). Modifier was found sorbed on the fibers of the coalescer. 


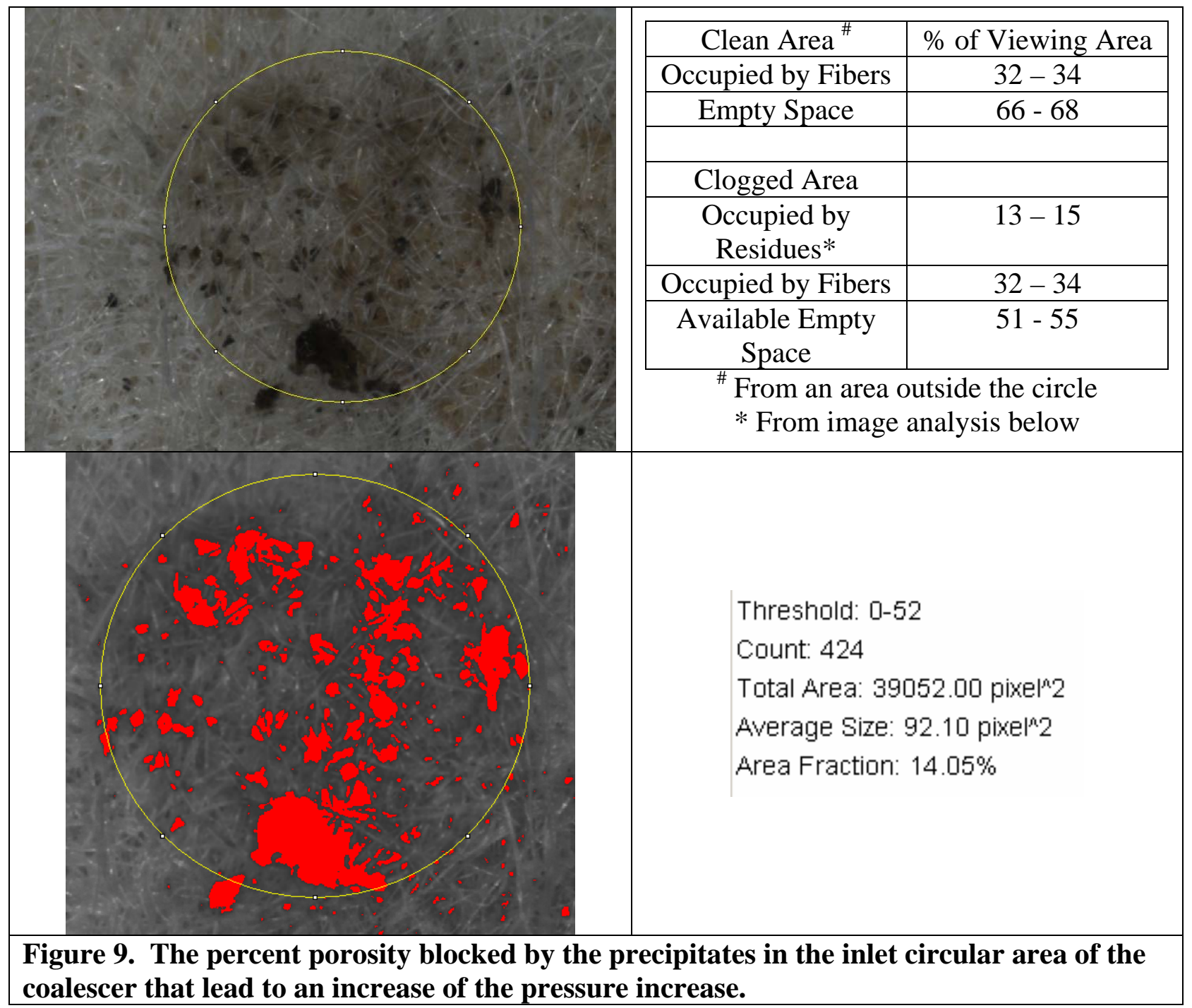

\section{CONCLUSIONS}

Conclusions from this testing include the following.

- Testing with the bench-scale coalescer showed an increase in pressure drop from solid particles, but the increase was not as large as observed at MCU.

- Cleaning the bench-scale coalescer with nitric acid reduced the pressure drop and removed a large amount of solid particles ( $11 \mathrm{~g}$ of bayerite if all aluminum is present in that form or $23 \mathrm{~g}$ of sodium aluminosilicate if all silicon is present in that form).

- Based on analysis of the cleaning solutions from bench-scale test, the "dirt capacity" of a 40 inch coalescer for the NAS solids tested is calculated as 450 - 950 grams.

- Cleaning the full-scale coalescer with nitric acid reduced the pressure drop and removed a large amount of solid particles (60 $\mathrm{g}$ of aluminum and $5 \mathrm{~g}$ of silicon). 
- $\quad$ Piping holdup in the full-scale coalescer system caused the $\mathrm{pH}$ to differ from the target value. Comparable hold-up in the facility could lead to less effective cleaning and precipitation of bayerite solid particles.

- Based on analysis of the cleaning solutions from the full-scale test, the "dirt capacity" of a 40 inch coalescer for these NAS solids is calculated as 40 - 170 grams.

\section{REFERENCES}

1. T. B. Peters, W. R. Wilmarth and S. D. Fink, “Assessment of Sodium Aluminosilicate Precipitation Behavior and Mitigation Approaches for MCU Test Program,” WSRC-TR-2007-00389, October 5, 2007.

2 T. B. Peters, M. R. Poirier, F. F. Fondeur, A. R. Jurgensen, and S. D. Fink, “Analysis of the Plugged Coalescer from MCU,” SRNL-CST-2007-00049, April 17, 2007.

3 T. B. Peters, F. F. Fondeur and S. D. Fink, "Evaluation of Propensity for Crusting of SodiumAluminosilicate Solids on the Coalescer Media,” SRNL-CST-2007-00073, July 31, 2007.

4 T. B. Peters, W. R. Wilmarth and S. D. Fink, "Interim report on Resolution of MCU Coalescer Issues,” SRNL-CST-2007-00062, May 24, 2007.

5 Modular Caustic Side Solvent Extraction Unit Operating Manual, SW9.2-IOP-MCU, Section 6.36, “Coalescer Media Chemical Flush,” Draft B, April 2, 2008. 